\title{
THE METABOLISM OF HYALURONIC ACID IN RELATION TO RHEUMATIC DISEASES*
}

\author{
BY
}

HENRY COHEN .

The diffidence with which I approach the subject of hyaluronic acid and rheumatism is born of a conjugation of both personal and general ignorance. Our. knowledge of the functional and intrinsic pathology of that group of locomotor disorders which we label "the rheumatic diseases" is so meagre that any new facts, however tenuous their nexus with rheumatism may appear to be, are seized on avidly and too often uncritically in the hope, as yet practically unrealized, that they will throw some light on the mechanisms of the "rheumatic" process. How comes it to be thought that a knowledge of hyaluronic acid and the enzyme, hyaluronidase, might help in the interpretation of the phenomena of rheumatic diseases?

I have argued previously that there is no common specific aetiology for the whole group of rheumatic disorders, but that they have two common features, namely, the site of attack and the structural changes they exhibit.

The site of the rheumatic lesion is in the skeletal tissues of mesenchymal origin, viz. connective tissue, fascia, muscle, ligament, joint capsule, synovial membrane, articular cartilage, and even bone. These all contain collagen.

The basic pathological lesions of rheumatism are, however, to be found not only in these tissues but also in the blood vessels which supply them. The basic lesion was described by Klinge as a fibrinoid degeneration or swelling of the collagen bundles of mature fibrous tissue. The earliest change is that of swelling of the fibres, which later show granular degeneration and fragmentation, and at the same time oedema occurs in the interstitial spaces. This leads to a partially necrotic area with fragmentation of surviving collagen fibres. There occurs also degeneration of the inter-fibrillar ground substance or cement. These foci act as irritants to the tissues, giving rise to inflammatory changes of a granulomatous type which may resolve by fibrosis. The vascular change has been described by Collins and

- This was the opening paper of a discussion on hyaluronic acid in rheumatic diseases at a meeting of the. Heberden Society on Oct. 16, 1948. others. It is essentially an arteritis involving all coats of the vessel and may lead to thrombosis.

I have mentioned that connective tissue consists essentially of collagen fibrils and of the interfibrillar ground substance or cement. Chemical studies have shown that amongst the constituents of this ground substance are chondroitin sulphuric acid and hyaluronic acid, and that both of these can be acted upon by the enzyme, hyaluronidase.

\section{Isolation of Hyaluronic Acid}

Hyaluronic acid was first isolated from bovine vitreous humour, and later studies have revealed its presence in other mucoid tissues, such as synovial fluid, connective and subcutaneous tissue, $\mathbf{A}$ and $\mathbf{C}$ haemolytic streptococci in the mucoid phase, and the capsule of the ovum. It is a simple viscous mucopolysaccharide, made up of equimolecular amounts of $\mathrm{N}$-acetylglucosamine and glucuronic acid. A detailed review covering its occurrence, chemistry, isolation, methods of estimation, the mechanism of the action of hyaluronidase on hyaluronic acid, the influence of such environmental factors as $p \mathrm{H}$ and salts, and of inhibitors such as heparin, chondroitin sulphate, gastric mucin and abnormal serum, is to be found in an article by Karl Meyer in Physiological Reviews. For our purpose it should be recalled that hyaluronic acid forms gels with proteins but is not antigenic.

The highest concentration of hyaluronic acid is found in mammals in the synovial fluid $(0.02$ to 0.05 per cent. in the normal but up to five times this quantity in the abnormal), and it is responsible for 80 to 90 per cent. of the viscosity of the fluid. That hyaluronic acid is a specific secretion of synovial cells is suggested by two facts: first, if synovial tissues be cultured they produce hyaluronic acid; and, secondly, that metastases from synoviomata also produce it.

\section{Hyaluronidase.}

The enzyme, hyaluronidase, breaks down hyaluronic acid apparently in two stages; first there is a rapid diminution in viscosity due, it is suggested, 
to depolymerization of the acid and, secondly, to its breaking up into its constituents- $\mathrm{N}$-acetylglucosamine and glucuronic acid. Hyaluronidase has an interesting history. In 1931 McLean showed that certain organisms produced a substance which markedly increased the area of spread of a dye injected into the subcutaneous tissues. This he called the spreading or diffusing factor. My interest in this factor arose from studies on the choroid plexus and ciliary body which revealed that their cells elaborate a spreading factor which plays a part in the diffusion of cerebrospinal and intra-ocular fluids. In 1939 Chain and Duthie showed that the activity of the spreading factor ran parallel with the hyaluronidase content of the extract, and it was later demonstrated that the spreading factor was almost certainly identical with hyaluronidase.

This enzyme is of wide distribution. It is found not only in such organisms as rough (Type II) pneumococci, $A$ and $C$ haemolytic streptococci, staphylococci, and many anaerobes, but also in leeches, snake venom, and especially in the testis, from which most preparations of hyaluronidase for experimental purposes have been made. There is considerable evidence that it is the hyaluronidase of the spermatozoon which enables the fertilization of the ovum to occur. The capsule of the ovum, as we have earlier noted, contains a considerable amount of hyaluronic acid, and is surrounded by granulosa cells clumped together by this acid; fertilization will occur only when the enzyme has so disrupted the acid that the sperm can enter. Almost certainly several hyaluronidases exist with differing actions on the mucopolysaccharides, and evidence of their specificity has been obtained by antigenic reactions.

It is then clear that when hyaluronidase acts on the mucopolysaccharides of connective tissue there may result (i) oedema of both tissue fibres and spaces, (ii) a fragmentation of collagen fibres and the intercellular cement, and (iii) a reduced viscosity of synovial fluid. This last is of considerable interest. The normal synovial fluid on dilution, acidification, and the addition of normal horse serum gives rise to a fibrinous clot, but pathological fluids subjected to similar treatment give simply a colloidal turbidity. If, however, a small amount of hyaluronidase $(0.01$ unit, which is insufficient to affect either viscosity or hyaluronic acid concentration) be added to a normal fluid and treated similarly, a colloidal turbidity similar to that found in pathological fluids occurs, suggesting the presence of an excess of hyaluronidase in the pathological fluid. This has been expressed quantitatively by the following formula:
Where $V=$ viscosity of fluid and $C_{H}=$ concentration of hyaluronic. acid determined turbidometrically, then $\frac{\log \mathrm{V}}{\mathrm{CH}_{\mathrm{H}}}$ exceeds 10 for normal fluids, and is less than 10 for pathological fluids, the activity of the disease being, roughly, inversely proportional to this factor.

Thus it appears that when the enzyme hyaluronidase attacks hyaluronic acid and other ground substances of connective tissue there occurs a series in of changes analogous to those seen in rheumatic diseases. But we must not fall victims to that most elementary of logical fallacies-the middle term-and assume that the same effect necessarily results from identical causes.

There are, however, a few published observations $\frac{0}{\infty}$ which suggest that studies of hyaluronic acid metabolism may yield useful information for our studies of rheumatic disease. First, Guerra has suggested that the beneficial effects of salicylates in rheumatism result from the antagonism of this drug and hyaluronidase which he and others claim to have demonstrated; their results have not always been confirmed, but it may well be that different forms of hyaluronidase have been used in the different experiments. Secondly, normal serum inhibits hyaluronidase in a non-specific manner, but this inhibitory power is said to be increased in rheumatic disorders possibly as a result of antigenic activity of hyaluronidase accompanying the disorder; there is, however, no clear indication that this is of great significance in "rheumatism". Thirdly, hyaluronic acid after intravenous injection prolongs the erythrocyte sedimentation rate in vitro, and it has been shown that purified testicular hyaluronidase decreases in vitro the E.S.R. of those suffering from rheumatic fever, but this is most likely to be due to spherocyte formation and not to direct antagonism of hyaluronidase and hyaluronic acid. And, $\delta$ fourthly, we may recall that certain organisms produce hyaluronidase and in this group are 을 haemolytic streptococci which have commonly been regarded as playing a part in the genesis of rheumatic disorders, but the evidence is conflicting $N$ and with many organisms no correlation has been o shown between hyaluronidase production and their $\tilde{O}$ virulence, or association with rheumatic disease.

\section{The Present Position}

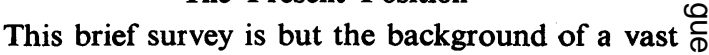
problem. It cannot be claimed that as a result of the $\stackrel{\oplus}{?}$ knowledge thus far attained we stand on the brink $T$ of a new era in our understanding of rheumatic disease. Indeed we cannot as yet assert that any $\stackrel{\mathbb{O}}{\stackrel{\mathbb{P}}{ }}$ direct association between hyaluronic acid meta- $\mathbb{\mathbb { Q }}$ bolism and rheumatism has been established. The 
evidence is, however, suggestive and a fruitful field of studdy has been revealed which merits further exploration. The history of rheumatism is itself the most forceful warning against the uncritical acceptance of hypotheses however intriguing, alluring, or seductive they might appear. We may mourn the slaughter of a beautiful hypothesis by an uncompromising fact, but the tragedy must unresentfully be accepted.

The most gratifying features of these researches on hyaluronic acid and hyaluronidase are, first, that they reveal the wider recognition of the fact that we must have a deeper understanding of the fundamental problems of connective tissue metabolism if we are to have a clearer knowledge of " rheumatism ", and, secondly, that they indicate that we are receding from an era in which the literature of rheumatic disease concerned itself, often exclusively, with the miraculous changes wrought by a specific elixir.

\section{Le Métabolisme de l'Acide Hyaluronique et ses Rapports avec les Affections Rhumatismales}

\section{Résume}

Lorsque l'acide hyaluronique et d'autres substances fondamentales du tissu conjonctif sont attaquées par l'enzyme hyaluronidase, il semble qu'il se produise une série de modifications analogues à celles que l'on observe dans les affections rhumatismales. Mais, remarque l'auteur, il ne faut pas succomber au sophisme qui consiste à conclure que les mêmes effets sont inévitablement produits par les mêmes causes.

Néanmoins, certaines observations publiées suggèrent que l'étude du métabolisme de l'acide hyaluronique pourrait fournir des renseignements utiles pour l'étude des affections rhumatismales. Premièrement, Guerra a suggéré que l'action favorable des salicylates dans le rhumatisme serait due à l'action inhibitrice de ce médicament sur l'hyaluronidase, que lui et ses collaborateurs croient avoir démontrée; leurs résultats n'ont pas toujours été confirmés, mais cela peut être dû à ce que l'on n'a pas toujours utilisé les mêmes formes d'hyaluronidase dans les différentes expériences.- Deuxièmement, le sérum normal inhibe l'hyaluronidase de façon non spécifique, mais ce pouvoir inhibiteur serait accru dans les affections rhumatismales peut-être par suite de l'activité antigénique de l'hyaluronidase présente au cours de cette maladie; il n'y a cependant aucune indication précise que ceci ait une grande importance dans le "rhumatisme". Troisièmement, l'acide hyaluronique injecté par voie intraveineuse abaisse la vitesse de sédimentation des globules rouges in vitro, et il a été prouvé que l'hyaluronidase testiculaire purifiée diminue in vitro la vitesse de sédimentation des globules rouges des malades atteints de rhumatisme articulaire aigu, mais ceci est très probablement dû à la formation de sphérocytes et non pas à l'antagonisme direct entre l'hyaluronidase et l'acide hyaluronique. Et, quatrièmement, on se souvient que certains micro-organismes produisent de l'hyaluronidase, dans ce groupe se trouvent les streptocoques hémolytiques qui ont été couramment considérés comme jouant un rôle dans la génèse des affections rhumatismales, mais les faits se contredisent et, dans le cas de nombreux microorganismes, on n'a pu démontrer aucune corrélation entre leur production d'hyaluronidase et leur virulence, ni leur association avec les affections rhumatismales.

Ces recherches sur l'acide hyaluronique et l'hyaluronidase sont surtout intéressantes, premièrement, parce qu'elles montrent que l'on admet de plus en plus la nécessité d'arriver à une compréhension plus complète des problèmes fondamentaux du métabolisme du tissu conjonctif pour clarifier nos connaissances sur le " rhumatisme", et, deuxièmement, parce qu'elles indiquent que nous dépassons la période pendant laquelle la littérature sur les affections rhumatismales ne s'intéressait, souvent exclusivement, qu'aux changements miraculeux produits par un élixir spécifique. 